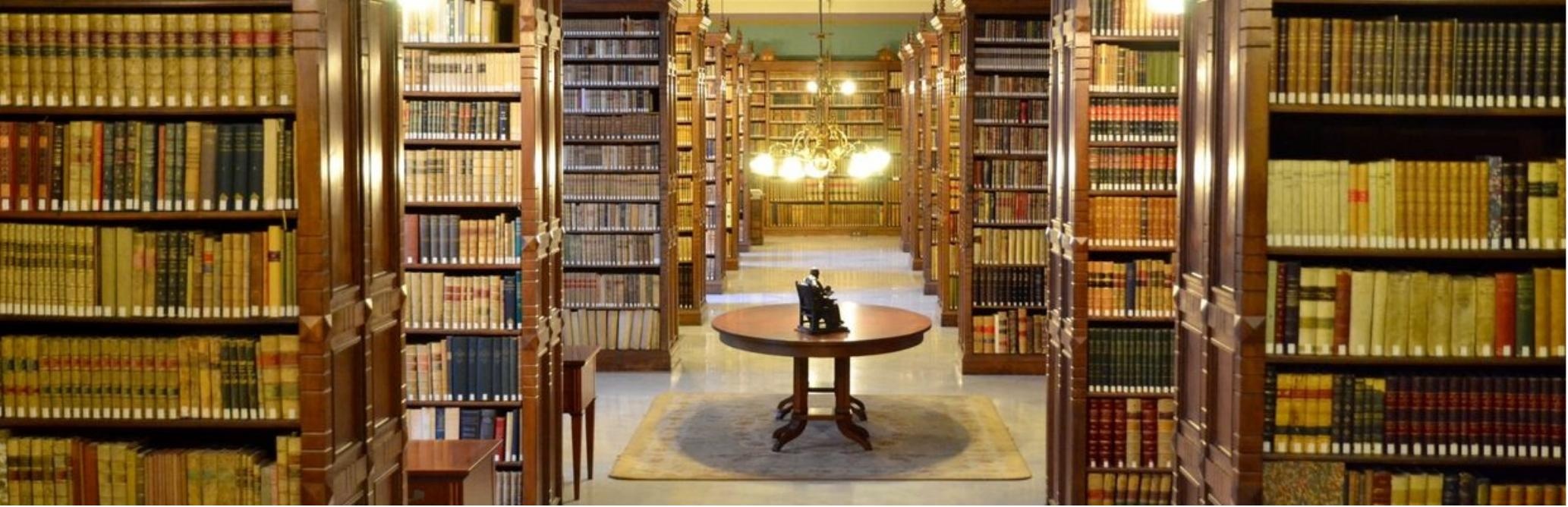

\title{
Editorial Volume 6, Issue 4
}

$\begin{aligned} \text { Authors: } & \text { María Fernanda Sandoval } \\ \text { Submitted: } & \text { 1. May 2019 } \\ \text { Published: } & \text { 3. May } 2019 \\ \text { Volume: } & 6 \\ \text { Issue: } & 4 \\ \text { Languages: } & \text { English } \\ \text { Keywords: } & \text { Editorial, Josha Journal, } 2019 \\ \text { Categories: } & \text { News and Views } \\ \text { DOI: } & 10.17160 / \text { josha.6.4.559 }\end{aligned}$

Abstract:

This year 2019 was wonderful as far as the purpose of our magazine is concerned. We were working together making visits to Schmelzeisen in Freiburg, Germany and preparing some changes in the Website. As you may have seen, now our readers are able to see the statistics with the exact number of views and downloads of every article. In the same way, we have added the option to filter all the articles according to the language you need just by clicking on the flags.

\section{JOSHA Jouma olseserea Humanities and Arts}




\section{JOSHA - Journal of Science Humanities and Arts Editorial Volume 6 Issue 4}

This year 2019 was wonderful as far as the purpose of our magazine is concerned.

We were working together making visits to Schmelzeisen in Freiburg, Germany and preparing some changes in the Website. As you may have seen, now our readers are able to see the statistics with the exact number of views and downloads of every article. In the same way, we have added the option to filter all the articles according to the language you need just by clicking on the flags.

$\mathbb{2}$

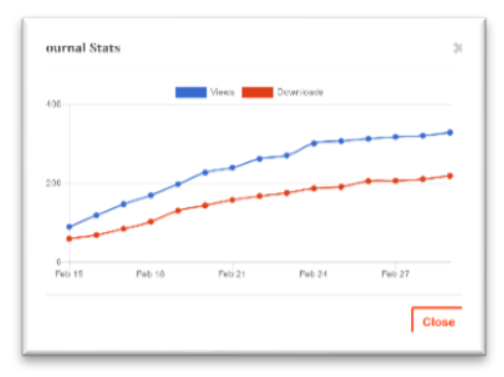

In another framework of ideas, we would like to remind you that you can immediately submit your work to participate in our Demetrios Prizes 2019. This time we are giving you again the opportunity to participate, to show to the world your researches and Ideas, and to win 500Euros. Follow the link of the title "DEMETRIOS PRIZE 2019" to see and get more information about this wonderful idea to promote and support the talent of young Students all around the world. The theses should be submitted by mail to admin@josha-archive.org until June 15, 2019.

In the same way, we were receiving around 100 articles that confirm a total of more than 300 articles since 2014 with more than 400,000 visits and more than 300,000 downloads. Concerning this last issue, a total of 6 articles belonging to the areas of medicine, architecture and design, music, visual arts, and politics were published in April.

\section{VISUAL ARTS, ARCHITECTURE, AND DESIGN}

In this field, JOSHA has brought to his readers a very interesting article. It was presented as the second part of the article "Interviewing Rainer Schmelzeisen: The Power of Light as Kinetic Art - Die Kraft des Lichts als

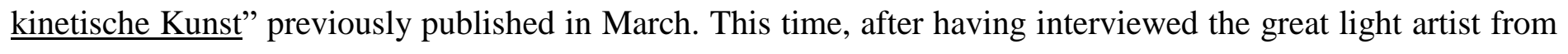
Freiburg, the JOSHA team has been invited to his art exhibition in Kirchzarten near Freiburg where we were able to see and enjoy the lights and colors in all his work. The article "Time will tell" the kinetic art exhibition of 


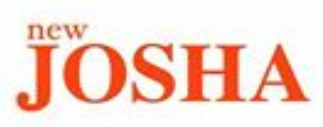

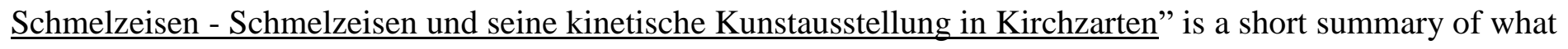
we saw and everything we experienced there.

As always in this category, JOSHA has published different papers from many different countries. This Issue concerns to three works from Kosovo, Colombia, and a partnership between Germany and Argentina. From Kosovo, we have got a very contemporary topic entitled. "Depression, anxiety and socio-demographic factors among hospitalized patients in Gjakova region, Kosovo This study was presented by Haxhi Kamberi, Naim Jerliu, Vanesa Sefa, Genc Burazeri in affiliation with the Faculty of Medicine of the University of Prishtina. The second work is a medical case report from Colombia, entitled "CASE REPORT: ORALLY TRANSMITTED ACUTE CHAGAS' DISEASE FROM A CASE IN A PUBLIC HOSPITAL IN BUCARAMANGA CITY, COLOMBIA.". This study is about a zoonosis named Chagas and was presented by Angie Katherine Bello Suárez, Patrik Eliana Sarmiento Wilches, and Luis Miguel Sosa Ávila in affiliation with the Universidad Industrial de Santander. We also like to present you the highlight of this Category, he has discovered and developed singleparticle cryo-electron microscopy (cryo-EM). He, Joachim Frank, received the Nobel Prize in Chemistry in 2017 which he shared with Jacques Dubochet and Richard Henderson. However, his article entitles "Nobel Laureate Joachim Frank receives an Honorary Ph.D. Degree of the Universidad Nacional de Cuyo, in Mendoza, Argentina:

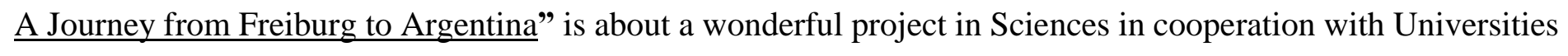
of Germany, Switzerland, and Argentina.

\section{MUSIC}

"A wonderful concert experience in Freiburg \Konzert-ERLEBNISSE" is another beautiful column from the series of columns about the classical music world in Germany. This column was written by Leander Hotaki, who is since 2010 the director of the German program called "Albert Konzerte" and brings the greatest artist of the World to Freiburg and to make the most wonderful concerts in the south-west of Germany. In this time he talks about the wonderful experiences many people enjoy when they have the opportunity to interact with the artists and musicians from all over the world who perform in the concert hall in Freiburg. 
SOCIAL \& LAW

So far in the Field of Social and Law, JOSHA has been publishing many interesting articles covering several topics. This time the article of this Category, entitled "Rückforderung von BerufungsLeistungsbezügen bei vorzeitigem Hochschulwechsel - BayVGH, Urt. vom 18.08.2017, 3 BV 16.132" has been published by our Journal thanks to the cooperative work of the Jurnal "Ordnung der Wissenschaft".

We are happy to carry on a successful way with all your support and hope to have a wonderful 2019 overflowing with endless interesting articles from all over the world. The Editorial Board and everybody in JOSHA would like to thank our readers and authors for supporting this project. We also like to remind that you can upload a Video link to your article as well as we invite you to visit our links directly to the upcoming events, to our prizes, and also see how you can become a member by clicking on the IASHA e.V. button.

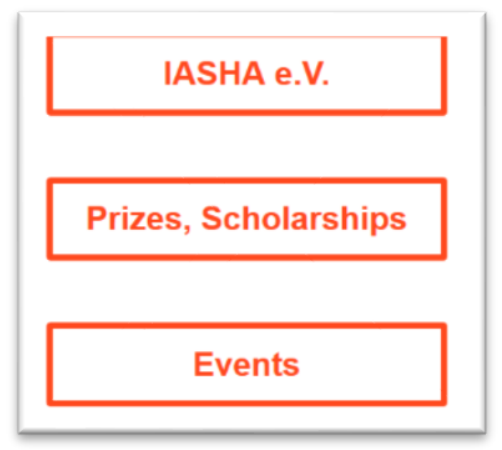

We wish all our readers a joyful reading experience at JOSHA.

Table of content: http://josha-journal.org/en/issues

Haxhi Kamberi, Naim Jerliu, Vanesa Sefa, Genc Burazeri, Depression, anxiety and socio-demographic factors among hospitalized patients in Gjakova region, Kosovo

Frank Wertheimer, Rückforderung von BerufungsLeistungsbezügen bei vorzeitigem Hochschulwechsel BayVGH, Urt. vom 18.08.2017, 3 BV 16.132

Joachim Frank, Nobel Laureate Joachim Frank receives an Honorary PhD Degree of the Universidad Nacional de Cuyo, in Mendoza, Argentina: A Journey from Freiburg to Argentina

Leander Hotaki, $\underline{A}$ wonderful concert experience in Freiburg \Konzert-ERLEBNISSE

Angie Katherine Bello Suárez, Patrik Eliana Sarmiento Wilches et al., CASE REPORT: ORALLY TRANSMITTED ACUTE CHAGAS' DISEASE FROM A CASE IN A PUBLIC HOSPITAL IN BUCARAMANGA CITY, COLOMBIA.

María Fernanda Sandoval, Zazie-Charlotte Pfeiffer, "Time will tell" the kinetik art exhibition of $\underline{\text { Schmelzeisen - Schmelzeisen und seine kinetische Kunstausstellung in Kirchzarten }}$ 